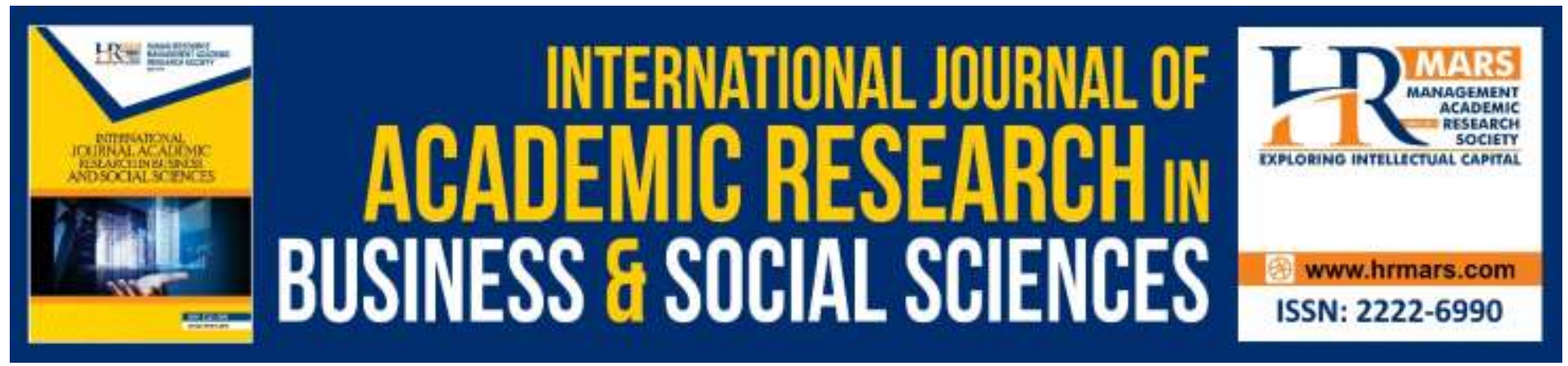

\title{
An Autoregressive Distributed-Lag Modeling Approach to Nigeria's External Reserves Dynamics
}

\author{
Ibrahim Shaibu, Famous I.O. Izedonmi
}

To Link this Article: http://dx.doi.org/10.6007/IJARBSS/v10-i2/6948

DOI:10.6007/IJARBSS/v10-i2/6948

Received: 20 January 2020, Revised: 01 February 2020, Accepted: 12 February 2020

Published Online: 29 February 2020

In-Text Citation: (Shaibu \& Izedonmi, 2020)

To Cite this Article: Shaibu, I., \& Izedonmi, F. I. O. (2020). An Autoregressive Distributed-Lag Modeling Approach to Nigeria's External Reserves Dynamics. International Journal of Academic Research in Business and Social Sciences, 10(2), 539-557.

\section{Copyright: (c) 2020 The Author(s)}

Published by Human Resource Management Academic Research Society (www.hrmars.com)

This article is published under the Creative Commons Attribution (CC BY 4.0) license. Anyone may reproduce, distribute, translate and create derivative works of this article (for both commercial and non-commercial purposes), subject to full attribution to the original publication and authors. The full terms of this license may be seen

at: http://creativecommons.org/licences/by/4.0/legalcode

\section{Vol. 10, No. 2, 2020, Pg. $539-557$}




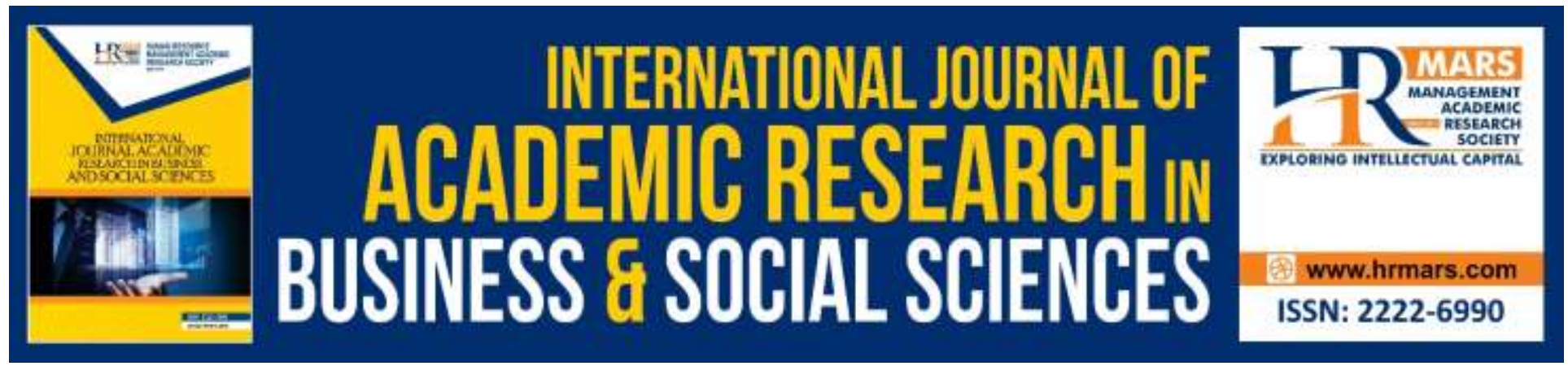

\title{
An Autoregressive Distributed-Lag Modeling Approach to Nigeria's External Reserves Dynamics
}

\author{
Ibrahim Shaibu, Ph.D. \\ Associate Professor, Department of Business Administration, University of Benin, Benin City \\ Email: ibb.shaibu2013@gmail.com
}

Famous I.O. Izedonmi, Ph.D. Professor, Department of Accounting, University of Benin, Benin City

Email: professorizedonmi@gmail.com

\begin{abstract}
The objective of this study was to develop and analyze a regression model that explains the dynamics of foreign exchange reserves in Nigeria by examining the short-run and long-run impacts of some macroeconomic variables (exchange rate, inflation, interest rate, crude oil price, and real gross domestic product) on foreign reserves in Nigeria from 1986 to 2018. The data were sourced from the publications of the Central Bank of Nigeria (CBN) and World Bank. Unit root and co-integration tests were performed on the variables before estimation. An empirical multivariate autoregressive distributed-lag model (ARDL) was identified, specified, and estimated with the aid of EViews econometric software. Diagnostic tests for serial correlation (BreuschGodfrey serial correlation LM test), normality (Jarque-Bera test), stability (CUSUM-of-squares test), and forecasting performance test were conducted to evaluate the estimated model. The study found that the estimated ARDL model could provide information on the behaviour of foreign exchange reserves in Nigeria. The regression results showed that none of the explanatory variables (exchange rate, inflation rate, interest rate, crude oil price, and real gross domestic product) shared contemporaneous and lagged relationship with foreign reserves dynamics in Nigeria. However, in the long run, only the previous value of foreign reserves was significant in explaining foreign reserves dynamics in Nigeria during the sample period. Given that foreign reserves play an important role in the design and evaluation of current and future macroeconomic policies aimed at achieving trade balance, the study makes the following recommendations: (1) government policies directed at managing and improving foreign reserves should largely consider the short-run and long-run behaviour of foreign reserves and these policies should be pursued with high degree of transparency because foreign reserves dynamics largely find explanation in adaptive expectation in Nigeria, (2) policy makers should ensure the
\end{abstract}


evolution of appropriate exchange rate policies and regimes that will enable the economy build its reserves and adequate and balanced reserves should be accumulated to help to smoothen out the volatility in the exchange rate only in the short run, (3) government and the relevant agencies should block all foreign reserves leakages in the economy by ensuring that foreign exchange allocation and utilization are purely for genuine economic purposes and build fiscal buffers through the replenishment of the Excess Crude Account or the Sovereign Wealth Fund, and (4) the implementation of appropriate policies to facilitate the diversification of the Nigerian economy along areas of key comparative advantage (such as agriculture and small scale labourintensive manufacturing).

Keywords: ARDL, Co-integration, Eviews, Unit root, CUSUM.

\section{Introduction}

Central banks in emerging market economies (EMEs) have over time broadened the range of assets and currencies in which they invest foreign exchange reserves, and sharpened their focus on generating returns in order to regulate their economies (Schanz, 2019). The foreign exchange (FX) reserves of emerging market economies (EMEs) have surged since the early 1990s. On average, the level reached almost 30\% of GDP in 2018 from about 5\% in 1990 (Arslan \& Cantú, 2019). Foreign reserves (or reserve assets in the balance of payments or international reserves or external reserves) are those external assets that are readily available to and controlled by a country's monetary authorities (IMF, 2009). Foreign exchange reserves include foreign banknotes, foreign bank deposits, foreign treasury bills, and short and long-term foreign government securities, as well as gold reserves, special drawing rights (SDRs), and International Monetary Fund (IMF) reserve positions (IMF, 2009). The main reasons for a country holding external reserves include direct financing of international payments imbalances, foreign exchange market stability, exchange rate stability, exchange rate targeting, external obligations with global partners, creditworthiness, transactions buffer, and emergency such as natural disasters (Archer \& Halliday, 1998; Arize, 2012; Arslan \& Cantú, 2019). To ensure that reserves are available at the times when they are needed most, liquidity (which is the ability to convert quickly reserve assets into foreign exchange), usually receives the highest priority, albeit with a cost that usually involves accepting lower yielding investment instruments. According to the IMF (2013), external reserves management is a process that ensures that adequate official public sector foreign assets are readily available to and controlled by the authorities for meeting a defined range of objectives for a country or union. It is therefore a part of the official public policies, and must be in line with achieving the national economic policies. In Nigeria, the Central Bank of Nigeria (CBN) Act 1991 vests the custody and management of the country's external reserves in the $\mathrm{CBN}$.

To date, Nigeria has adopted some strategies in managing its exchange reserve which include First Tier Official Exchange Rate (FOER), Second Tier Foreign Exchange Rate (SFEM), Dutch Auction System (DAS), Dual Exchange Rate Policy, and Inter-Bank Foreign Exchange Market, and Autonomous Foreign Exchange Market (AFEM) but yet Nigeria's external reserves have been fluctuating over the years. However, the objective of a sustained and stable increase in Nigeria's foreign reserves has not been attained. 
The stock of external reserves of Nigeria which was US\$ 9.91billion in 2000 rose by $5.09 \%$ in 2001 and later dropped to US\$7.47 billion at the end of December 2003 but increased by $127.00 \%$ to US\$16.96 billion in 2004. In 2005 the stock of external reserves increased further by $66.80 \%$ to US\$28.28 billion, and in 2006 , reserves rose to an all-time high of US\$42.20 billion. The external reserves continues to move in an upward trend until in 2009 when the economy witnessed another fall in reserves to the tune of $20 \%$ from 2008 reserves position of US\$53.00 billion and it continues in that direction till 2013. The last time Nigeria's reserves opened above $\$ 42$ billion was in 2013, when it opened at above $\$ 45$ billion. For 2014, 2015, 2016, 2017, and 2018 , the reserves stood at $\$ 40.6$ billion, $\$ 34.2$ billion, $\$ 28.2$ billion, 27.9 billion, $\$ 38.9$ billion and $\$ 43.1$ billion respectively. Nigeria's foreign reserves dropped by $\$ 812$ million to $\$ 40.95$ billion within three weeks in 2019, according to the Central Bank of Nigeria (CBN) data. At $\$ 40.95$ billion, the country's external reserves hit the lowest reserves in 2019. In July 2019, the reserves peaked at $\$ 45$ billion. With this new figure, the country has lost about $\$ 5$ billion in foreign reserves. At the end of its Monetary Policy Committee meeting in October 18th, 2019, the CBN attributed the decline in external reserves to weakening oil prices and various interventions in the foreign exchange market. Members, however, suggested that there is a need to avoid monetary policy responses that could worsen the capital flows position, and hence external reserves and exchange rate stability. Evidence suggests that the depletion in foreign reserves witnessed in Nigeria could elevate risk concerns among foreign investors. This could have serious implications for risk premium, portfolio flows, short-term external debt position, balance of payment position and economic growth. Also dwindling fiscal buffers tend to increase the country's reliance on foreign portfolio flows which are known to be volatile and characterized by sudden stop constitute a major risk to exchange rate stability, especially with uncertainties around capital flows and oil price.

One reason that has been adduced for the failure of most policy measures in Nigeria is the relatively weak scientific effort at explaining the dynamics of the policy objectives. As a result, policy making has relied upon macroeconomic forecasts that are not anchored on scientific models that track major economic indices (Adenikinju, Busari \& Olofin, 2009). Given the limited resources available to support development and reforms, it is not possible to tackle all possible constraints and therefore the country as a matter of necessity must prioritize. Understanding the determining variables of external reserves in Nigeria is prerequisite to its management. This is useful to enable economic decision makers exercise their judgmental analyses in a much more structured and quantified manner and to develop a more adequate understanding of macroeconomic time lines.

The objective of this study was to develop and analyze a regression model that shows the short-run and long-run dynamics of foreign exchange reserves in Nigeria. This study attempted to do this by identifying and estimating a dynamic model based on Pesaran, Shin, \& Smith (2001) multivariate autoregressive distributed lag (ARDL) approach. The value addition of this study is that Nigeria being the most populous black nation and a leading economy in Africa can provide empirical evidence for the purposes of generalization in the matter of foreign reserves dynamics. Another value addition is our estimation technique. An advantage of the ARDL approach is that it can be used to simultaneously estimate short-term and long-term relationships irrespective of the order of integration of the regressors (Ghatak \& Siddiki, 2001). 


\section{Review of Literature}

According to the International Monetary Fund (2009), foreign exchange reserves (or reserve assets in the balance of payments) are those external assets that are readily available to and controlled by a country's monetary authorities. These reserves are used to back liabilities and influence monetary policy. They comprise foreign currencies, other assets denominated in foreign currencies, gold reserves, special drawing rights (SDRs) and IMF reserve positions. These reserves may be used for direct financing of international payments imbalances or for indirect regulation of the magnitude of such imbalances via intervention in foreign exchange markets in order to affect the exchange rate of the country's currency. The foreign reserve holding behavior of developing countries differs in some ways from that of advanced countries. For one thing, the developing countries hold more reserves. Many studies have found that reserves, sometimes expressed as a ratio to the money supply and sometimes as a ratio to short-term debt, would have been a useful predictor of the emerging market crises of the 1990s. Consequently, after the emerging market crises of the 1990s, the traditional rule of thumb that developing countries should hold enough reserves to equal at least three months of imports was replaced by the "Guidotti rule." This guideline determined that developing countries should hold enough reserves to cover all foreign debt that is short-term or maturing within one year. Most emerging market countries worked to increase their holdings of reserves strongly, typically raising the Guidotti ratio of reserves to short-term debt from below one to above one. The motive was precautionary, to self-ensure against the effects of future crises

Sound reserve management practices are important because they can increase a country's overall resilience to shocks. Through their interaction with financial markets, reserve managers gain access to valuable information that keeps policy makers informed of market developments and views on potential threats. Sound reserve management policies and practices can support, but not substitute for, sound macroeconomic management. Moreover, inappropriate economic policies (fiscal, monetary and exchange rate) can pose serious risks to the ability to manage reserves. Therefore, reserve management should seek to ensure that adequate foreign exchange reserves are available for meeting a defined range of objectives. Reserve management forms a part of official economic policies, and specific circumstances will impact on choices concerning both reserve adequacy and reserve management objectives. In order to ensure the availability of reserves, and as part of setting appropriate investment priorities, the reserve manager needs to have an assessment of what constitutes an adequate level of reserves. Such an assessment may be made by the reserve management entity, or it may involve consultation between the reserve management entity and other agencies. There are no universally applicable measures for assessing the adequacy of reserves and the determination of reserve adequacy.

\section{Composition, Ownership Structure, and Management of Nigeria's External Reserves}

Foreign reserves play an important role in the design and evaluation of current and future macroeconomic policies aimed at achieving trade balance (Arize, 2012). Nigeria's external reserves are mainly from the proceeds of crude oil production and sales. Nigeria produces crude oil in joint venture with some international oil companies, notably Shell, Mobil, and Chevron. Out of this, Nigeria sells a predetermined proportion directly, while the joint venture partners sell the 
rest. The joint venture partners pay Petroleum Profit Tax to the Federal Government through the Federal Board of Inland Revenue. The five categories of revenue from crude oil production and sales are direct sales (NNPC), petroleum profit tax (oil companies), royalties, penalty for gas flaring and rentals. Other sources of external reserves in Nigeria include income from investing foreign reserves, repatriation of unutilized Wholes Sale Dutch Auction System (WDAS), interest on WDAS, accounts held by deposit money banks, WDAS purchases, inward money transfer, value added tax (VAT), education tax, commission, etc.

In term of composition of external reserves in Nigeria, the Central Bank of Nigeria Act 1991 vests the custody and management of the country's external reserves in the Central Bank of Nigeria (CBN). The Act provides that the CBN shall at all times maintain a reserve of external assets consisting of all or any of the following: a) gold coin or bullion; b) balance at any bank outside Nigeria where the currency is freely convertible and in such currency, notes, coins, money at call and any bill of exchange bearing at least two valid and authorized signatures and having a maturity not exceeding ninety days exclusive of grace; c) treasury bills having a maturity not exceeding one year issued by the government of any country outside Nigeria whose currency is freely convertible; d) securities of or guarantees by a government of any country outside Nigeria whose currency is freely convertible and the securities shall mature in a period not exceeding ten years from the date of acquisition; e) securities of or guarantees by international financial institutions of which Nigeria is a member, if such securities are expressed in currency freely convertible and maturity of the securities shall not exceed five years; f) Nigeria's gold tranche at the International Monetary Fund; g) allocation of Special Drawing Rights made to Nigeria by the International Monetary Fund (IMF).

In terms of ownership structure, Nigeria's external reserves comprise of three components. Nigeria's external reserves by virtue of statute are segregated into three distinctive portions, namely the Central Bank of Nigeria (CBN), the Federal Government of Nigeria (FGN) and Federation reflecting ownership of the reserves. The CBN consists of funds that have been monetized and shared. This arises as the Bank receives foreign exchange inflows from crude oil sales and other sources of revenue on behalf of the government. Such proceeds are purchased by the Bank and the Naira equivalent credited to the Federation account and shared, each month, in accordance with the constitution and the existing revenue sharing formula. The monetized foreign exchange, thus, belongs to the CBN. It is from this portion of the reserves that the Central Bank of Nigeria conducts its monetary policy and defends the value of the Naira. The Federal Government component consists of funds set aside by the FGN to finance its obligations and to which the $\mathrm{CBN}$ has no discretion. These funds represent funding from government savings (such as the NNPC), grants, recoveries, or bilateral cooperation for financing its Joint Venture expenses; Ministry of Defence, for Letters of Credit opened on its behalf; etc. The Federation component consists of sterilized funds (un-monetized) funds held in the excess crude and petroleum profit $\operatorname{tax}(\mathrm{PPT}) /$ Royalty accounts at the CBN belonging to the three tiers of government. This portion has not yet been monetized for sharing by the federating units. These are essentially the Government's savings of excess proceeds of crude oil, (PPT) and oil royalty.

Managing external reserves is one of the core mandates of the Central Bank of Nigeria (CBN) as stipulated in Section 2 (c) of the CBN Act of 2007. The Act vested the maintenance and management of Nigeria's external reserves on the CBN in order to safeguard the international 
value of the Naira. In addition, it is to maintain confidence in Nigeria's monetary and exchange rate policies, as well as provide confidence to the international community that the country is able to meet its external obligations. The CBN through interventions in the foreign exchange market supports monetary policy implementation by maintaining exchange rate stability and liquidity management. The problems of reserve management began during the periods of the First National Development Plan in 1962 to 1966 and the Nigerian Civil War of 1967 to 1970. In these periods, financing the plan and the war consumed a large portion of the country's reserves. The problems became compounded immediately after the war in the wake of the Federal Government's efforts to reconstruct and reactivate the war-ravaged economy which continued to demand immense foreign exchange reserves (Olawoyin, 2007; Osuji \& Ebringa, 2012). Odozi (2000) noted that in addition to the problem of depleting reserves, Nigeria faced a new scenario with reserve management following the admission into the Organization of Petroleum Exporting Countries (OPEC) in 1973 and the oil boom era. The problem of reserve management switched from that of "inadequate" to that of "excess reserves". This remained so until 1981 when the country was hit by the global economic recession that led to a consistent decline in her external reserves. In the light of this development, economic stabilization measures revolving stringent exchange control, which ran from April 1982 to June 1986 (when growth process to external reserves was low), were introduced. By the end of 1985, it was evident that the use of stringent economic control was ineffective in restraining external reserves depletion. To this end, exchange and trade controls were discontinued in 1986, following the adoption of market based policy measures, the Structural Adjustment Programme (SAP) in July 1986.

\section{Empirical Literature on the Determinants of Foreign Reserves}

The external reserve holding has generated serious global interest, as different economies search for alternative strategies that will protect their economies against financial instability and stimulate economic growth. Global official reserves have increased significantly and quite rapidly in recent years. The phenomenal growth is a reflection of the enormous importance countries attach to holding adequate level of international reserves (Osigwe, Okechukwu \& Onoja, 2015). Generally, a country needs foreign exchange reserves mainly for two reasons, 1) to synchronize its receipt and payments with the rest of the world; and 2) to withstand occasional speculative raid by the dealers in the foreign exchange market. It somewhat resembles the household precautionary demand for cash balance. In view of the above, management of external reserve stands as one of the integral core functions of Central Bank of any nation including Nigeria (Akinwunmi \& Adekoya, 2016).

Approaches to the management of reserves vary from country to country depending on the objectives at hand. In the context of fixed or managed exchange rate regimes, the traditional objectives have mostly been formulated with respect to monetary policy and exchange rate management (Carlos, Pierre, Joachim, Francis, \& Simone, 2004; Mendoza, 2004). In this case, foreign reserves act as a buffer against capital outflows in excess of the trade balance. Holding foreign reserves under both fixed and floating exchange rate regimes also acts as a "shock absorber" in terms of fluctuations in international transactions, such as variations in imports resulting from trade shocks, or in the capital account due to financial shocks. Therefore, there is need for intervention to smooth exchange rate fluctuations. Over the past three decades, Nigeria 
has taken numerous policy initiatives and measures in the management of its external reserves. Currently, Nigeria is operating the managed-float system which means that the Central Bank of Nigeria (CBN) should intervene occasionally in the exchange rate market to prevent excessive short-term exchange rate volatility. This is to ensure foreign exchange stability. Since exchange rate regime is bi-polar in nature, a country either practices floating exchange rate, with its inherent exchange rate volatility or fixed exchange rate with its attendant difficulties in absorbing changes in equilibrium real exchange rate. Although, between these two extremes are variety of mixed regimes, but whichever method a country adopts, of course, has its inherent consequences (Michael, Christopher, \& Marc, 2006).

A number of studies have been carried out on different aspects of external reserves management. The determinants of reserves holding reported in the literature can be grouped into five categories: economic size, current account vulnerability, capital account vulnerability, exchange rate flexibility, and opportunity cost. In the literature per capita GDP is used as indicator of economic size. The vulnerability of current account can be captured by such measures as export and import. Capital account vulnerability increase with financial openness and potential for resident based capital flight from the domestic currency. Consequently reserves should be positively correlated with such variables. Exchange rate flexibility is usually important; it reduces the demand for reserves, since central banks no longer need a large stockpile of reserves to manage a pegged exchange rate. Because there is "fear of floating" flexibility is generally measured by the actual volatility of the exchange rate. There is an opportunity cost of holding reserves, because the monetary authority swaps high-yield domestic assets for low yield foreign ones. It corresponds to the difference between the yield on reserves and marginal productivity of an alternative investment. This variable is, however, likely reflecting measurement problems.

The IMF (2003) developed an empirical model that incorporates various determinants of reserves holding. The model was estimated using a large panel that covers 122 emerging market economies with annual data from 1980 to 1996. In the study real per capita GDP, the population level, the ratio of import to GDP, and the volatility of the exchange rate are found to be statistically significant determinants of real reserves. Khan and Ahmed (2005) analyzed the main determinants of reserves holding in Pakistan from 1982 to 2003 using quarterly data. The study estimated the long run co-integration relationship between reserves variable and other determinants such as balance of payments variability, money market rate, the average propensity to import, the level of imports and workers' remittances. The study found a stable long run reserve demand function. The estimated co-integration relationship shows that all variables except remittances are significant. The variations in balance of payments and imports have positive relationship while money market rate has a negative impact on international reserves.

Prabheesh (2013) empirically determined the optimal level of international reserves for India by explicitly incorporating the country's sovereign risk associated with default of external debt due to financial crisis. The empirical result shows that the volatility of foreign institutional investment, short-term debt to reserves and the fiscal deficit to GDP significantly explains the variations in risk premium. The study suggests that international reserves in India are higher than the estimated optimum level of reserves. Suheyla and Yaman (2005) study on optimal reserves and its adequacy in Turkey between 1998 and 2002 indicated that actual reserves were below 
the optimal and adequate levels, when a cumulative GDP loss in excess of 5.0 per cent during a financial crisis is imposed on the entire sample period. Jeanne and Rancière (2006) argue that reserves allow the country to smooth domestic absorption in response to sudden stops, but yield a lower return than the interest rate on the country's long-term debt.

Chin-Hong, Mohamad, and Oi-Khim (2011) studied the relationship between international reserves and its determinant such as, economic size, exchange rate, balance of payments and the opportunity cost of reserves holding in Malaysia for the period 1975 to 2007. The co-integration test techniques were employed in the study. The test results showed that the international reserves and the specified determinants were co-integrated. Chowdhury, Uddin, and Islam (2014) applied the Engle Granger residual based co-integration approach to analyze the determinants of foreign exchange reserves from 1972 to 2011 using yearly time series data in Bangladesh. The empirical results confirm the existence of a strong relationship among foreign exchange reserves, exchange rate, remittance, home interest rate, broad money, export, import and per capita GDP.

In the context of Nigeria economy, research on the determinants of foreign exchange reserves has received some attention. Abdullateef and Waheed (2010) studied the determinant of foreign reserves by investigating the impact of change in external reserve positions of Nigeria on domestic investment, inflation rate, and exchange rate from 1986 to 2006. Using the ordinary least squares (OLS) and vector error correction (VEC) estimation methods, they found that change in external reserves in the country were influenced by foreign direct investment (FDI) and exchange rates, and domestic investment and inflation rates had no significant influence on foreign exchange reserves. Irefin and Yaaba (2012) employed an autoregressive distributed lag (ARDL) approach to estimate the determinants of foreign reserves in Nigeria over the period of 1999 to 2011, with focus on income, monetary policy rate, imports and exchange rate. The results showed that income was a major determinant of reserves holdings in Nigeria. Umeora (2013) carried out a study on foreign exchange reserves accumulation and macroeconomic stability in Nigeria. The study deal with time series figures from the period of 1986-2011. Unit root test were employed to test whether the time series data being used are stationary or not, co-integration test were same time employed to know if there is any correlation between the variables while multiple regression were also employed to know the level of significant of the variables mentioned on external reserves. The results of the tests show that exchange rate and GDP have positive and significant relationship with FER accumulation while inflation has negative and insignificant relationship with FER.

Abiola and Adebayo (2013) examined the demand for reserves in Nigeria and concluded that Nigeria's foreign reserve were adequate, based on international benchmarks. Udo and Antai (2014) suggest that reserves accumulation in Nigeria had an adverse impact on investment and economic productivity, and recommended a cut back in reserve accumulation to finance domestic investment. Osigwe, Okechukwu, and Onoja (2015) evaluated the determinants of foreign reserves in Nigeria using the cointegration and Error Correction Model (ECM). The results of the estimated short run coefficients indicated that real gross domestic product, oil exports are positive and significant determinants of foreign reserves. Exchange rate was found to be significant but negative determinant of foreign reserves. Foreign direct investment (FDI) inflows positively and significantly determine foreign reserves only in its first period lag while lending 
rate was discovered to be a negative and insignificant determinant. Similarly, the coefficient of inflation rate was negative and significant determinant of foreign reserves.

Ndubuaku, and Ifeanyi (2019) did a study on exchange rate and foreign reserves interface in Nigeria using time series data from 1996 to 2016. Applying the Auto Regressive Distributed Lag Model (ARDL), they found a positive but non-significant relationship between nominal exchange rate and foreign reserves in Nigeria. This makes a case for proper policy direction in the management of exchange rate in a manner that produces the best economic results for the Nigerian economy. The results are considered useful for economies in the shape of Nigeria for generalization and policy direction in the management of foreign reserve.

The reviewed literature revealed that a number of studies have examined the relationship between some macroeconomic variables foreign reserves in Nigeria. With no attempt of reinventing the wheel, this study employed the Pesaran, Shin, and Smith (2001) multivariate autoregressive distributed lag ( $A R D L)$ modeling technique to evaluate the determinants of foreign exchange reserves in Nigeria. The autoregressive distributed lag (ARDL) approach is a cointegration technique for determining long-run and short-run relationships among variables under study. An advantage of the ARDL approach is that it can be used to simultaneously estimate short-term and long-term relationships irrespective of the order of integration of the regressors (Ghatak \& Siddiki, 2001).

\section{Theoretical Framework and Model Specification}

Various models have been developed to measure the determinants of foreign reserves. The most widely used of these models in the literature is the Frenkel and Jovanovic (1981) "buffer stock model" (see Aizenman \& Marion, 2004; Flood \& Marion, 2002; Heller, 1966; IMF, 2003; Ramachandran, 2005). The advantage of the model over others is its adaptability to both fixed and floating exchange regimes.

The buffer stock model of Frenkel and Jovanovic (1981) is given as:

$$
d R(t)=\mu d t+\sigma d W(t)
$$

Where: $R(t)=$ reserves held in time $t$

$\mathrm{Wt}=$ standard Weiner process with zero mean and variance $\mathrm{t}$

$\mu=$ deterministic part of the instantaneous change in reserves

$\sigma=$ standard deviation of the Weiner increment in reserves

At each point in time the distribution of reserves holdings $\mathrm{R}(\mathrm{t})$ is characterized by

$$
R(t)=R^{*}-\mu d t+\sigma d W(t)
$$

where: $R^{*}$ is the optimal stock of reserves, which is obtained by minimizing two types of costs viz: i) the cost of adjustment, which is incurred once reserves reach an undesirable lower bound; and ii) foregone earnings on reserve holdings. The optimal stock of reserves is obtained by minimizing these two costs and it yields an expression:

$$
R^{*}=\sqrt{\left[2 c \sigma^{2} /\left(2 r c \sigma^{2}\right) 0.5\right]}
$$

where:

$c=$ fixed cost of adjustment

$r=$ opportunity cost of holding reserves 
$\sigma=$ standard deviation of change in reserves.

The estimating equation can be re-written as:

$$
\log R_{t}=\alpha_{0}+\alpha_{1} \log \sigma_{t}+\alpha_{2} \log r_{t}+\mu_{t}
$$

where $\mu_{\mathrm{t}}$ is white noise.

For a developing economy like Nigeria, there is need to modify the model to incorporate variables that are peculiar in the determination of reserves holdings. Hence, the model of this study includes foreign reserve as the dependent variable and exchange rate, inflation, interest rate, crude oil price and real gross domestic product as the explanatory variables. Thus, the equation becomes:

$$
R E S E V=f(E X C R T, I N F R T, I N T R T, \text { OILPR, RGDP })
$$

The autoregressive representation of the model can be stated as:

$$
R_{E S E V}=\alpha_{0}+\alpha_{1} R_{E S E V} V_{t-1}+\alpha_{2} E_{X X R T_{t}}+\alpha_{3} I N F R T_{t}+\alpha_{4} I N T R T_{t}+\alpha_{5} \operatorname{OILPR}_{t}+\alpha_{6} R G D P_{t}+\varepsilon_{t}
$$

where:

RESEV $=$ Foreign Reserve EXCRT $=$ Exchange Rate INFRT $=$ Inflation Rate; INTRT $=$ Interest Rate OILPR $=$ Crude Oil Price; RGDP $=$ Real Gross Domestic Product; $\varepsilon=$ Error Term

In order to develop model that captures the short-term and long-term relationship between the explanatory variables and foreign reserves, the research adopts the econometric technique of the autoregressive distributed-lag (ARDL) model introduced by Pesaran, Shin, and Smith (2001). The autoregressive distributed lag (ARDL) approach is a regression technique for determining short-run and long-run relationships among variables under study simultaneously. The ARDL approach is extensively used in regression modelling primarily because it can be applied irrespective of the order of integration of the series (Banerjee, Dolado, \& Mestre, 1998; Ghatak \& Siddiki, 2001) and can therefore be estimated directly as a multivariable single equation. Following Pesaran, Shin, and Smith (2001), the autoregressive distributed lag (ARDL) representation of the model (Equation 4) is specified in Equation 7 as follows:

$$
\begin{aligned}
\triangle \text { RESEV }_{t} & =\alpha_{0}+\sum_{i=1}^{n} \alpha_{1 i} \Delta R E S E V_{t-i}+\sum_{i=0}^{n} \alpha_{2 i} \Delta E X C R T_{t-i}+\sum_{i=0}^{n} \alpha_{3 i} \Delta I N F R T_{t-i}+\sum_{i=0}^{n} \alpha_{4 i} \Delta I N T R T_{t-i}+\sum_{i=0}^{n} \alpha_{5 i} \Delta O I L P R_{t-i} \\
& +\sum_{i=0}^{n} \alpha_{6 i} \Delta R G D P_{t-i}+\beta_{1} R E S E V_{t-1}+\beta_{2} E \operatorname{SXCRT}_{t-1}+\alpha_{3} \text { INFRT }_{t-1}+\beta_{4} I N T R T_{t-1} \\
& +\beta_{5} \text { OILPR }_{t-1}+\beta_{6} R G D_{t-1}
\end{aligned}
$$

The left-hand side of the model (Equation 7) is foreign reserves. The terms with the summation signs $\alpha_{1}$ to $\alpha_{6}$ on the right-hand side of the model (Equation 7) represent the shortrun relationship of the model. The first to the sixth term with beta signs $\beta_{1}$ to $\beta_{6}$ on the righthand side of the model (Equation 5 ) correspond to the long-run relationship of the model.

\section{Empirical Results}

The analyses were carried out in two phases. The first phase was some pre-estimation analyses. As this study involves time series data, the ordinary least squares (OLS) method cannot be applied unless it is established that the variables are stationary. To this end, the graphical 
analysis was performed to ascertain the historical performance of the variables used in the study, the summary statistics was examined to ascertain the distribution of the variables, and the Augmented Dickey-Fuller unit root test was performed to ascertain the stationarity of the variables selected for the model. The co-integration test was performed to ascertain if there is a long-run stable relationship among the variables and the correlation test was performed to examine the strength and direction of the linear relationship among the variables. The second phase was the estimation and post-estimation analyses (diagnostics testing) of the model.

\section{Pre-estimation Analysis}

Before estimation, the graphs of the time series under study are plotted, descriptive statistics are displayed, unit root test for the variables are performed, and co-integration analysis is done on the variables. The figure below shows the line graphs of the historical performance of the variables used in this study.
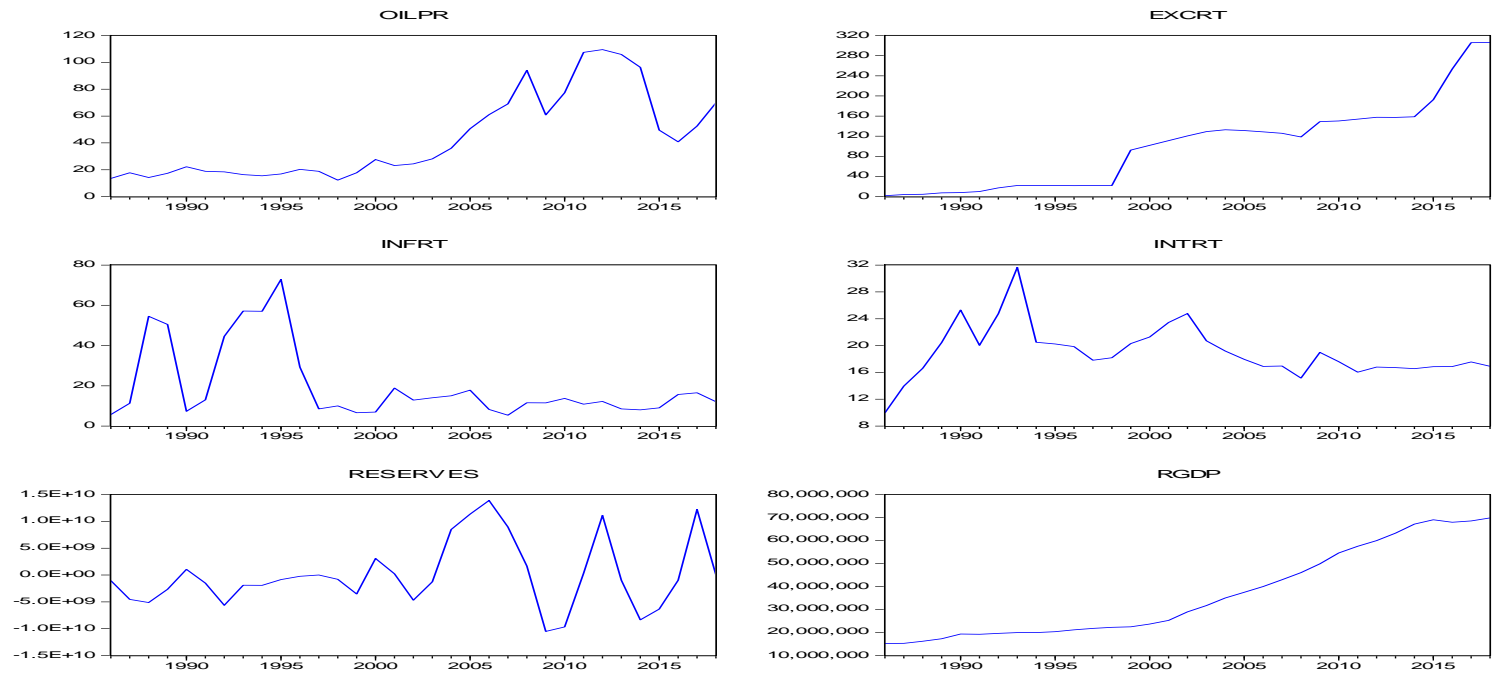

Figure 1: Variables at Levels

Source: Researchers' calculation by EViews (2019).

Figure 1 shows the multiple graphs of the series at their level form. The graphs show that there is little evidence to suspect the presence of structural break or outlier in the six variables but the graphs of series display a stable variance.

\section{Descriptive Statistics}

The descriptive statistics of the variables were conducted. Table 1 below provides a descriptive statistics of the macroeconomic variables used for the research work. 
INTERNATIONAL JOURNAL OF ACADEMIC RESEARCH IN BUSINESS AND SOCIAL SCIENCES

Vol. 10, No. 2, Feb, 2020, E-ISSN: 2222-6990 @ 2020 HRMARS

Table 1: Descriptive Statistics of Variables in Nigeria (1986-2018)

\begin{tabular}{|l|l|l|l|l|l|l|l|}
\hline Returns & Mean & Median & $\begin{array}{l}\text { Std. } \\
\text { Dev. }\end{array}$ & $\begin{array}{l}\text { Skewnes } \\
\text { s }\end{array}$ & Kurtosis & $\begin{array}{l}\text { Jarque- } \\
\text { Bera }\end{array}$ & Observations \\
\hline EXCRT & 101.85 & 118.55 & $\mathbf{8 5 . 9 8}$ & $\mathbf{0 . 6 6}$ & $\mathbf{2 . 9 0}$ & $2.43(0.30)$ & 33 \\
\hline INFRT & $\mathbf{1 9 . 9 2}$ & 12.22 & $\mathbf{1 8 . 2 9}$ & $\mathbf{1 . 6 1}$ & $\mathbf{4 . 2 2}$ & $16.32(0.00)$ & 33 \\
\hline INTRT & 18.99 & 17.95 & $\mathbf{3 . 8 9}$ & $\mathbf{0 . 9 3}$ & $\mathbf{5 . 2 9}$ & $11.94(0.00)$ & 33 \\
\hline OILP & 43.15 & 27.60 & $\mathbf{3 1 . 6 6}$ & $\mathbf{0 . 9 0}$ & $\mathbf{2 . 4 5}$ & $4.87(0.09)$ & 33 \\
\hline RESEV & $\begin{array}{l}1125703 \\
9\end{array}$ & $-\mathbf{0 . 0 0}$ & $\mathbf{0 . 0 0}$ & $\mathbf{0 . 7 1}$ & $\mathbf{3 . 0 0}$ & $2.79(0.25)$ & 33 \\
\hline RGDP & $\begin{array}{l}3662491 \\
7\end{array}$ & $\begin{array}{l}2895771 \\
0\end{array}$ & $\begin{array}{l}\mathbf{1 9 4 2 0 3 4} \\
\mathbf{6}\end{array}$ & $\mathbf{0 . 5 7}$ & $\mathbf{1 . 7 6}$ & $3.88(0.14)$ & 33 \\
\hline
\end{tabular}

Table 1 provides a summary statistics of the macroeconomic variables used for the study. As may be observed from the table, foreign reserves (RESEV) has the lowest mean value of 11257039 and the mean value of real gross domestic product (RGDP) has the highest value of 36624917. The skewness is a measure of the symmetry of the histogram while the kurtosis is a measure of the tail shape of the histogram. The bench mark for symmetrical distribution for the skewness is how close the variable is to zero while in the case of kurtosis, when it three is called mesokurtic but value lower than that is called platykurtic and above is referred to as leptokurtic. The result of the Jarque-Bera (JB) statistics showed that exchange rate, foreign reserves, and real gross domestic product are normally distributed while inflation rate, interest rate, and crude oil price are not normally distributed. The descriptive statistics show that the variables have some variations and using them in the models will require identifying their stationary properties.

\section{Unit Root Tests for the Variables}

The use of ARDL models does not impose pre-testing of variables for unit root problems. However, unit root tests are conducted in this study to find out if there are mixtures in the order of integration of our variables. The order of integration of the time series was investigated by applying the Augmented Dickey-Fuller (1979) test. The Augmented Dickey-Fuller (ADF) unit root test results for the time series variables are presented in Table 2 below.

Table 2: Unit Root Test Results

\begin{tabular}{|l|l|l|l|l|l|}
\hline Variable & $\begin{array}{l}\text { ADF } \\
\text { Statistic } \\
\text { Level }\end{array}$ & $\begin{array}{l}\text { ADF Test } \\
\text { at }\end{array}$ & $\begin{array}{l}\text { 95\% Critical ADF } \\
\text { Value }\end{array}$ & $\begin{array}{l}\text { Order of } \\
\text { Integration }\end{array}$ & Remark \\
\hline EXCRT & 1.306 & $-3.98^{*}$ & $-2.960^{*}$ & $I(\mathbf{1})$ & Stationary \\
\hline INFRT & -2.688 & $-6.86^{*}$ & -2.964 & $I(\mathbf{1})$ & Stationary \\
\hline INTRT & $-3.340^{*}$ & & -2.960 & $I(\mathbf{0})$ & Stationary \\
\hline OILPR & -1.304 & $-4.76^{*}$ & -2.957 & $I(\mathbf{1})$ & Stationary \\
\hline RESEV & $-4.948^{*}$ & & -2.968 & $I(\mathbf{0})$ & Stationary \\
\hline RGDP & -0.000 & $-5.885^{*}$ & -2.964 & $I(\mathbf{2})$ & Stationary \\
\hline
\end{tabular}

Source: Researchers' calculation by EViews (2019). 
The ADF tests in Table 2 show that interest rate (INTRT) and reserves (RESEV) are stationary at level; exchange rate (EXCRT), inflation rate (INFRT), interest rate (INTRT), and crude oil price (OILPR) are stationary at first difference; while real gross domestic product (RGDP) is stationary at second difference. Thus co-integration test must be performed on the variables.

\section{Co-Integration Test}

The Engel and Granger (1987) co-integration test is used for single equation models. The co-integration test result for the research model is presented. Using the Engel and Granger twostage technique, the co-integration test result for the research model is presented in Table 3 below.

Table 3: Engel and Granger Residual Based Co-Integration Test

\begin{tabular}{|c|c|c|c|c|}
\hline SERIES & $A D F$ & 5\% CRITICAL VALUE & $\begin{array}{ll}\text { ORDER } & \text { OF } \\
\text { INTEGRATION } & \end{array}$ & REMARK \\
\hline RESIDUAL & -4.38 & -2.96 & $I(0)$ & Co-integrated \\
\hline
\end{tabular}

Source: Researchers' calculation by EViews (2019).

The results in Table 3 show that there is co-integration among foreign reserves (RESEV), exchange rate (EXCRT), inflation (INFRT), interest rate (INTRT), crude oil price (OILPR), and real gross domestic product (RGDP). Since the ADF test value for the residual is greater than the critical value, it is said to be stationary. Thus, the time series are co-integrated, implying that a long-run stable relationship exists among the variables used in this study. This means that any short-run deviation in their relationships would return to equilibrium in the long-run.

\section{ARDL Model Estimation and Diagnostics}

The autoregressive distributed-lag (ARDL) is a technique that allows us to simultaneously estimate the short-run and long-run coefficients of a specified model. The estimated autoregressive distributed lag (ARDL) model is presented in Table 4.

Table 4: The Parametized (ARDL) Estimates

Dependent Variable: D(RESEV)

Sample (adjusted): 19882018

Included observations: 31 after adjustments

\begin{tabular}{lllll}
\hline \hline Variable & \multicolumn{2}{l}{ Coefficient Std. Error } & t-Statistic & Prob. \\
\hline \hline C & $-3.96 E+08$ & $1.78 E+10$ & -0.022201 & 0.9826 \\
D(RESEV(-1)) & 0.412615 & 0.309493 & 1.333198 & 0.2054 \\
D(EXCRT) & -10035655 & $1.12 E+08$ & -0.089553 & 0.9300 \\
D(EXCRT(-1)) & 97694047 & $1.67 E+08$ & 0.584992 & 0.5686 \\
D(INFRT) & -71927441 & $1.44 E+08$ & -0.501143 & 0.6246 \\
D(INFRT(-1)) & 92849987 & $1.49 E+08$ & 0.622239 & 0.5445 \\
D(INTRT) & $-2.14 E+08$ & $5.54 E+08$ & -0.386313 & 0.7055 \\
D(INTRT(-1)) & $-4.21 E+08$ & $4.36 E+08$ & -0.965330 & 0.3520
\end{tabular}


INTERNATIONAL JOURNAL OF ACADEMIC RESEARCH IN BUSINESS AND SOCIAL SCIENCES

Vol. 10, No. 2, Feb, 2020, E-ISSN: 2222-6990 @ 2020 HRMARS

\begin{tabular}{|c|c|c|c|c|}
\hline D(OILPR) & 66402295 & $1.19 \mathrm{E}+08$ & 0.555763 & 0.5878 \\
\hline D(OILPR(-1)) & $1.53 E+08$ & $1.85 \mathrm{E}+08$ & 0.825378 & 0.4240 \\
\hline $\mathrm{D}(\mathrm{RGDP})$ & 112.1890 & 2862.151 & 0.039197 & 0.9693 \\
\hline $\mathrm{D}(\mathrm{RGDP}(-1))$ & 1317.135 & 2085.286 & 0.631633 & 0.5386 \\
\hline RESEV(-1) & -0.744864 & 0.408426 & -1.823742 & 0.0913 \\
\hline EXCRT(-1) & -66025319 & $1.52 \mathrm{E}+08$ & -0.434554 & 0.6710 \\
\hline INFRT(-1) & -91094644 & $1.97 \mathrm{E}+08$ & -0.462608 & 0.6513 \\
\hline INTRT(-1) & -47810392 & $5.46 \mathrm{E}+08$ & -0.087507 & 0.9316 \\
\hline OILPR(-1) & $-1.58 \mathrm{E}+08$ & $2.86 \mathrm{E}+08$ & -0.551714 & 0.5905 \\
\hline RGDP(-1) & 357.8898 & 826.8192 & 0.432851 & 0.6722 \\
\hline R-squared & 0.629866 & \multicolumn{2}{|c|}{ Mean dependent var } & 1.47E+08 \\
\hline Adjusted R-squared & 0.145844 & \multicolumn{2}{|c|}{ S.D. dependent var } & $6.49 E+09$ \\
\hline S.E. of regression & $6.00 E+09$ & \multicolumn{2}{|c|}{ Akaike info criterion } & 48.15991 \\
\hline Sum squared resid & $4.68 \mathrm{E}+20$ & \multicolumn{2}{|c|}{ Schwarz criterion } & 48.99255 \\
\hline Log likelihood & -728.4786 & \multirow{2}{*}{\multicolumn{2}{|c|}{$\begin{array}{l}\text { Hannan-Quinn criter. } \\
\text { Durbin-Watson stat }\end{array}$}} & 48.43133 \\
\hline F-statistic & 1.301317 & & & 2.070355 \\
\hline Prob(F-statistic) & 0.319126 & & & \\
\hline
\end{tabular}

Source: Researchers' calculation by EViews (2019).

After estimating the empirical ARDL model, a variety of diagnostic tests were carried out to enhance the credibility of the model. The serial correlation (Breusch-Godfrey serial correlation LM) test, the normality (Jarque-Bera) test, the forecasting performance (RMSE and MAE) test, and the stability (cumulative sum of squares, CUSUM-SQ) test were conducted. The results of the respective tests are presented in Table 6 and Figure 2.

Table 5: ARDL Diagnostic Tests

\begin{tabular}{|l|l|l|}
\hline TEST & F-statistic (p-value) & Forecast Value \\
\hline $\begin{array}{l}\text { Serial Correlation: Breusch-Godfrey serial } \\
\text { correlation LM test }\end{array}$ & $1.38(0.29)$ & \\
\hline Normality: Jarque-Bera test. & $1.21(0.54)$ & \\
\hline Root Mean Square Error (RMSE) & & 0.000 \\
\hline Mean Absolute Error (MAE) & & 0.000 \\
\hline
\end{tabular}

Source: Researchers' calculation by EViews (2019).

The diagnostics indicate that the residuals were serially uncorrelated and normally distributed based on Breusch-Godfrey serial correlation LM test and Jarque-Bera test respectively. When forecast values are closer to each other, a small forecast error will be obtained. Thus, smaller RMSE and MAE are preferred. The results show that the model is relevant for forecasting economic growth in Nigeria. The stability properties of the ARDL model were examined. We applied the cumulative sum (CUSUM) test, which Brown, Durbin, and Evans (1975) developed. According to Bahmani-Oskooee and Wing NG (2002), if the plot of these statistics remains within the critical bound of the $5 \%$ significance level, the null hypothesis (that is, all 
coefficients in the model are stable) cannot be rejected. A graphical presentation of this test for our ARDL model is provided in Figure 2 below.

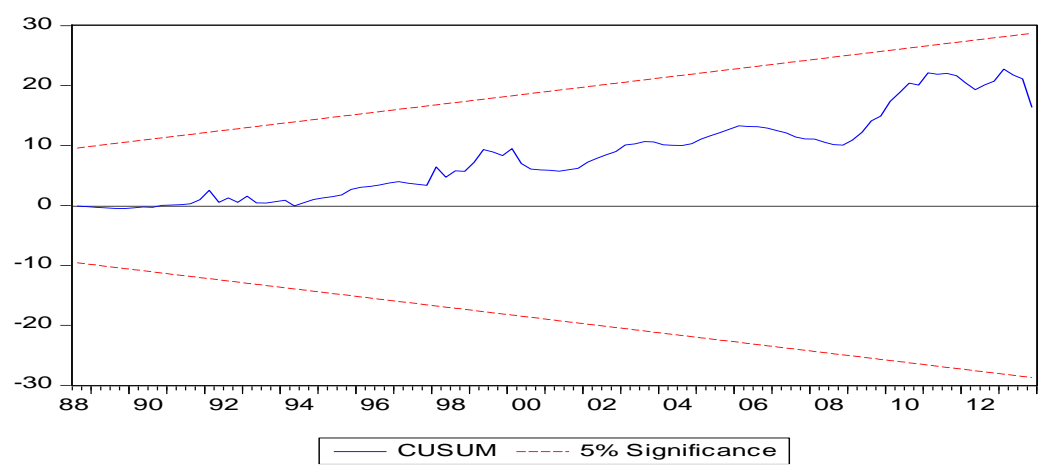

Figure 2: Cumulative sum (CUSUM) of recursive residuals plot. Source: Researchers' calculation by EViews (2019).

Since the plot of the cumulative sum (CUSUM) statistic for foreign reserves does not cross the critical value lines as Figure 2 indicates, it is therefore safe to conclude that ARDL foreign reserves model is stable and foreign reserves can be used as a target variable.

\section{Findings, Conclusion, and Recommendations}

This study empirically investigated the short run and long run impacts of exchange rate, inflation, interest rate, crude oil price, and real gross domestic product on foreign reserves by employing the ARDL modeling technique in Nigeria from 1986 to 2018. The data were sourced from the publications of the Central bank of Nigeria (CBN) and the World Bank. The study found that ARDL model can provide information both on the short-run and on the long-run behaviour of foreign reserves in Nigeria. The diagnostic tests of the model show that the ARDL model performs very well. In other words, this ARDL model can be applied in explaining the dynamics of foreign reserves in Nigeria. The coefficient of determination $\left(R^{2}=0.63\right)$ of the estimated model shows that about $63 \%$ of the changes in foreign reserves in Nigeria is jointly is jointly explained and accounted for by the selected variables in the estimated ARDL model. The regression results showed that none of the explanatory variables (exchange rate, inflation rate, interest rate, crude oil price, and real gross domestic product) share contemporaneous and lagged relationship with foreign reserves dynamics in Nigeria. However, in the long run, only the previous value of foreign reserves had a negative $(-0.74)$ and significant $(10 \%)$ impact on foreign reserves dynamics in Nigeria during the sample period. We conclude from the empirical findings that exchange rate, inflation rate, interest rate, crude oil price, and real gross domestic product do not have significant impacts on the dynamics of foreign reserves in Nigeria both in the short run and in the long run. We also conclude from the empirical findings that only the previous value of foreign reserves was significant in explaining foreign reserves dynamics in Nigeria during the sample period and in the long run.

On the basis of the findings and conclusions, we make the following recommendations:

1. Foreign reserves play an important role in the design and evaluation of current and future macroeconomic policies aimed at achieving trade balance. Since the results showed that past 
values of foreign reserves influence the current value of foreign reserves in the long run, it means that foreign reserves dynamics largely find explanation in adaptive expectation theory in Nigeria. We therefore recommend that government policies directed at managing and improving foreign reserves should largely consider the short-run and long-run behaviour of foreign reserves. This should be pursued with high degree of transparency because foreign reserves dynamics largely find explanation in adaptive expectation in Nigeria.

2. There seems to be no significant relationship between the exchange rate and foreign reserves in the Nigeria context given that foreign reserves are dollar denominated hence may not be affected by nominal changes in the domestic exchange rate. We therefore recommend that policy makers should ensure the evolution of appropriate exchange rate policies and regimes that will enable the economy build its reserves. This is made necessary by the fact that reserves provide buffer in times of economic difficulties especially for developing economies like Nigeria. In addition to this, adequate and balanced reserves have to be accumulated to help to smoothen out the volatility in the exchange rate only in the short run.

3. We recommend that government and the relevant agencies should block all foreign reserves leakages in the economy by ensuring that foreign exchange allocation and utilization are purely for genuine economic purposes and build fiscal buffers through the replenishment of the Excess Crude Account or the Sovereign Wealth Fund.

4. The over dependence on the oil and gas sector in foreign revenue generation remains a point of concern. We paper recommend the implementation of appropriate policies to facilitate the diversification of the Nigerian economy along areas of key comparative advantage (i.e. agriculture and small scale labour-intensive manufacturing). This would help mitigate the impact of external shocks on the foreign exchange earnings base of the economy, and eventually help narrow the discounted risk premium as the economic fundamentals improve.

\section{References}

Abdullateef, U., \& I. Waheed, I. (2010). External reserve holdings in Nigeria: Implications for investment, inflation and exchange rate. Journal of Economics and International Finance, 2 (9), 183-189.

Abiola, A. G., \& Adebayo, F. O. (2013). Channelling the Nigeria's foreign exchange reserves into alternative investment outlets: A critical analysis. International Journal of Economics and Financial Issues, 3 (4), 813-826

Adenikinju, A., Busari, D., \& Olofin, S. (2009). Applied econometrics and macroeconometric modelling in Nigeria. Ibadan: Ibadan University Press.

Aizenman, J., \& Marion, N. (2004). International reserve holding with sovereign risk and costly tax collection. Economic Journal, 114 (July), 569-591.

Akinwunmi, A. K., \& Adekoya, R. B. (2016). External reserves management and its effect on economic growth of Nigeria. International Journal of Business and Finance Management Research, 4, 36-46.

Archer, D., \& Halliday, J. (1998). The rationale for holding foreign currency reserves. Reserve Bank of New Zealand Bulletin, 61 (4), 346-354.

Arinze, A. C. (2012). Foreign exchange reserves in Asia and its impacts on import demand. International Journal of Economics and Finance, 4 (3), 55-68. 
Arslan, Y., \& Cantú, C. (2019). The size of foreign exchange reserves. In reserves management and foreign exchange intervention (pp. 1-25). Bank for International Settlements, No 104.

Bahmani-Oskooee, M., \& Wing NG, R.C. (2002). Long-run demand for money in Hong Kong: An application of the ARDL model. International Journal of Business and Economics, 1 (2), 147155

Banerjee, A., Dolado, J., \& Mestre, R. (1998). Error correction mechanism tests for cointegration in a single equation framework. Journal of Time Series Analysis, 19 (3), 267-283.

Carlos, B., Pierre, C., Joachim, C., Francis, X. D., \& Simone, M. (2004). Risk management for central bank foreign reserves. European Central Bank, April.

CBN. (2007). Building and managing external reserves for economic development. The CBN Bullion, 31 (2), 24-36.

Chin-Hong, P., Mohamad, J., Affendy, A., \& Oi-Khim, L. (2011). Determinants of international reserves in Malaysia. International Journal of Business Research, 11(4). 28-39.

Chowdhury N. M., Uddin, M. J., \& Islam, M. S. (2014). An econometric analysis of the determinants of foreign exchange reserves in Bangladesh. Journal of World Economic Research, 3 (6), 72-82.

Dickey, D. A., \& Fuller, W. A. (1979). Distribution of the estimators for autoregressive time series with a unit root. Journal of the American Statistical Association, 74, 427-431.

Engle, R. F., \& Granger, C. W. J. (1987). Cointegration and error-correction: Representation, estimation, and testing. Econometrica 55.

Flood, R. P., \& Marion, N. P. (2002). International reserves in an era of high capital mobility. International Monetary Fund, Washington, DC, IMF Working Paper, No. WP/02/62.

Frenkel, J. A., \& Jovanovic, B. (1981). Optimal international reserves. Economic Journal, 91 (362), 507-14.

Ghatak, S., \& Siddiki, J. (2001). The use of ARDL approach in estimating virtual exchange rates in India. Journal of Applied Statistics, 28(5), 273-583.

Heller, R. (1966). Optimal international reserves. Economic Journal, 76, 296-311. International Monetary Fund (2003). Reserve management guidelines. Available at www.imf.org

International Monetary Fund. (2009). International Monetary Fund, Annual Report. Available at www.imf.org/external/pubs/ft/ar/2009/eng/pdf/a1.pdf

International Monetary Fund. (2013). Selected decisions and selected documents of the IMF, Thirtieth Issue - Surveillance over Exchange Rate Policies, Legal Department of the IMF, W ashington.

Irefin, D., \& Yaaba, B. N. (2012). Determinants of foreign reserves in Nigeria: An autoregressive distributed lag approach. CBN Journal of Applied Statistics, 2 (2), 63-82.

Jeanne, O., \& Rancière, R. (2011). The optimal level of international reserves in emerging market countries: A new formula and some applications. The Economic Journal, 121, September 2011.

Kalu, E. U., Ugwu, O. E., Ndubuaku, V. C., \& Ifeanyi, O. P. (2019). Exchange rate and foreign reserves interface: Empirical evidence from Nigeria. The Economics and Finance Letters, $6(1), 1-8$. 
Khan, A., \& Ahmed, M. (2005). The demand for international reserves: A case study of Pakistan, The Pakistan Development Review, 44 (4), 939-957

Mendoza, R. U. (2004). International reserve-holding in the developing world: Self insurance in crisis-prone era. Emerging Markets Review, 5 (1), 61-82.

Michael, D. B., Christopher, M. M., \& Marc, D. W. (2006). Currency mismatches, default risk, and exchange rate depreciation: Evidence from the end of Bimetallism. WEF Working Papers 0010, ESRC World Economy and Finance Research Programme, Birkbeck, University of London.

Odozi, V. (2000). Foreign exchange management: The role of CBN. CBN Bullion. 10(3):17-22.

Olawoyin, G. A. (2007). Reserves management in Nigeria. A paper presentation, CBN. 31(2):1923.

Osigwe, A. C., Okechukwu, A. I., \& Onoja, T. C. (2015). Modelling the determinants of foreign reserves in Nigeria. Developing Country Studies, 5 (19), 72-77.

Osuji C. C., \& Ebiringa O. T. (2012). Analysis of effect of external reserves management on macroeconomic stability of Nigeria. Int. J. Bus. Manage. Econ. Res., 3 (6),646-654.

Pesaran, M. H., Shin, Y., \& Smith, R. J. (2001). Bounds testing approaches to the analysis of level relationships. Journal of Applied Econometrics, 16 (3), 289-326.

Prabheesh. (2013). Optimum international reserves and sovereign risk: Evidence from India. Journal of Asian Economics (Elsevier Publication), 28, 76-86

Ramachandran, M. (2005). High capital mobility and precautionary demand for international reserves. Journal of Quantitative Economics, July 2005.

Schanz, J. (2019). Reserve management in emerging market economies: Trends and challenges. In reserves management and foreign exchange intervention (pp. 26-45). Bank for International Settlements, No 104.

Suheyla, O., \& Yaman, B. (2005). Optimal versus adequate level of international reserves: Evidence for Turkey. Applied Economics, 37, 1557-1569.

Udo, A. B., \& Antai, A. S. (2014). Opportunity cost of Nigeria's external reserves. Journal of Economics and Finance (IOSR-JEF), 3 (5), 7-16

Umeora, C. E. (2013). Foreign exchange reserves accumulation and macro-economic stability: The Nigerian experience. Int. J. Bus. Manage. Invent, 2 (9), 150-157. 